\title{
IAMJ
}

INTERNATIONAL

AYURVEDIC

MEDICAL JOURNAL

Review Article

ISSN: 2320-5091

Impact Factor: 6.719

\section{A REVIEW - PAIN MANAGEMENT THROUGH MARMA CHIKITSA}

\section{Dhakad Jyoti ${ }^{1}$, Marwaha Rita ${ }^{2}$, Bhalerav Nisha ${ }^{3}$}

${ }^{1}$ M.D. Scholar; ${ }^{2}$ M.D. Ayurveda, HOD, Professor; ${ }^{3}$ M.D. Ayurveda, Reader

P.G. Department of Rachna Sharir, Pt. Khusilal Sharma Govt. (Auto.), Ayurvedic College and Hospital, Bhopal, Madhya Pradesh, India

Corresponding Author: jyotidhakad22@gmail.com

\section{https://doi.org/10.46607/iamj3309072021}

(Published Online: July 2021)

\section{Open Access}

(C) International Ayurvedic Medical Journal, India 2021

Article Received: 08/06//2021 - Peer Reviewed: 05/07/2021 - Accepted for Publication: 06/07/2021

\section{Check for updates}

\begin{abstract}
Marma is literary communicate the sense of vital part of the body, these points are important in human body and injuries or mechanical involvement directly affecting the site of Marma. In Vedic Science, Chikitsa is divided into four parts Atharvani, Anagirasi, Daivi and Manushyja. The basics of Marma Chikitsa Considered as Angirasi Chikitsa. In this Rasa refer to the executive elements that control and carries out the various function of the body. Any trauma to Marma will surely produce pain or can cause death. Thus, the Marma Chikitsa help in maintaining the vitality of the body and treatment of disease.
\end{abstract}

Keywords: Marma, Pain, Shula, Vedna, Marma Chikitsa

\section{INTRODUCTION}

Marma Science and Marma Chikitsa is an untouched chapter of Indian surgery. With the exploration of Marma science the whole scenario of Indian surgery may change in multidimensional approaches. ${ }^{1}$ These Marmas are mentioned and discussed in Sushrut Samhita as an anatomical consideration of different parts of the body. ${ }^{2}$ Firm unions of Mansa (muscles), Sira (veins), Snayu (ligaments), Ashti (bones) or Sandhi (bone-joints) are called Marmas (or vital parts of the body) which naturally and specifically form the seats of life (Prana), and hence a hurt to any one of the Marmas invariably produces such symptoms as arise from the hurt of a certain Marma. ${ }^{3}$ There are one hundred and seven (107) Marmas (vital spots) in the body. ${ }^{4}$ In 
the chapter on the Marma, in his commentary on the Sushrut Samhita Dr Ghanekar writes- the definition of Marma is mentioned in Different texts as vital parts may lead to death. It is also true about the heart and brain. Trauma to these parts may lead to loss of vitality so these parts are known as vital parts. ${ }^{5}$ The word "Marma" comes from Sanskrit origin "Mra" means place of Prana (life). Any direct or indirect trauma to these sites may be fatal or can result in the disability of the person. These Marmas points harmonize the nervous and endocrine system and normalize different pathology in the body through vital power itself, with proper stimulations/Manipulation. This technique is known as Marma Chikitsa. ${ }^{6}$

\section{MARMA CHIKITSA}

Marma Chikitsa contributes to increase or recharge physical, mental and spiritual energies. On the physical level, it helps to revitalize or reenergize the body tissues; at the cellular level, it improves vital functions like digestion, respiration, blood circulation and excretion. On the psychological level, it improves the mental faculty by directing it in a positive direction. It also offers a way to treat many psychosomatic ailments without any drugs. It harmonizes the functioning of nervous and endocrine systems to control psychological disorders. On the spiritual level, the reasoning of mind, regulation and transformation of thoughts in a positive direction helps to concentrate towards the ultimate goal of life. As a preventive measure, it helps to cope with the situations arising from different diseases. $^{7}$

\section{PAIN-}

Pain is indispensable for survival. It serves a protective function by signalling the presence of noxious, tissuedamaging conditions. From a medical standpoint, the subjective description and indication of the location of pain may help pinpoint the underlying cause of the disease. $^{8}$

Nociceptors- the receptors for pain, are free nerve endings found in every tissue of the body except the brain. Intense thermal, mechanical, or chemical stimuli can activate nociceptors. Tissue irritation or injury releases chemicals such as prostaglandins, kinins, and potassium ions $(\mathrm{K}+)$ that stimulate nociceptors. Pain may persist even after a pain-producing stimulus is removed because pain-mediating chemicals linger and because nociceptors exhibit very little adaptation. Conditions that elicit pain include excessive distention (stretching) of a structure, prolonged muscular contractions, muscle spasms, or ischemia (inadequate blood flow to an organ). ${ }^{9}$

\section{MARMA AND SHULA}

Pain is one of the most common features of traumatic lesions and understanding its nature and properties is important for the successful management of pain. In Ayurvedic medicinal therapy, this is the only lacuna, that is, the immediate management of pain. Marma Science and Chikitsa have an answer to this and hence, if we incorporate Marma science in the broad field of Ayurvedic therapy, we can overcome this lacuna. Marma science also draws its basic premises from the same body of texts as the other disciplines of Ayurvedic practice. ${ }^{10}$ Marmas are considered as half of the surgery subject as any injury to Marmas Can prove to be fatal so if the patient is promptly treated by the skilled doctor even though the patient will suffer from excessive pain. $^{11}$ In Susruta Samhita, Maharshi Susruta has mentioned that the commonest cause of pain is Vata. ${ }^{12}$ Wound and pain are both coexisting features of trauma. Pain is a feeling of uneasiness. In Ayurveda, Vedana, Dukha, Pida, Sula, Ruk, Ruja, Bheda, Sadana, Avasada, are words used for pain. According to Susruta Samhita, the main causative factor of pain is Vata. The seat of pain is mana (psyche) and Sharira (body). ${ }^{13}$ In all cases of Vatika predominance, the chances of pain are quite common along with other clinical presentations of Vatika anomalies. In a normal state, the Vata is responsible for the activation of several functions of different systems. ${ }^{14}$ According to the Astanga-hridaya, Sutrasthana 12/49-50, derangement, displacement, dilatation, piercing pain, anaesthesia, lethargy, pricking and incising pain, constricting pain, breaking pain, twisting pain, excitation of the hair follicle and thirst due to severe pain, tremor, hardening, porosity, dryness, stimulation, spasm, distaste of mouth, black and reddish black discolouration are due to the Vata. 
According to Susruta Samhita, Marmas causing pain are predominant in qualities of Agni and Vayu as they particularly cause pain; some on the other hand quote that pain is related to all five elements (Panchamahabhutas). ${ }^{15}$

\section{TYPES OF PAIN IN WOUND— ${ }^{16,17}$}

Vatika Vedana:-Todana (pricking pain), Bhedana (cutting/ incising pain), Tadana (pain due to blunt injury), Chedana (cutting/ excising pain), Ayamana (stretching pain), Manthana (gripping pain), Viksepana (pulling pain), Cumcumayana (tingling sensation), Nirdahana (burning pain), Avabhanjana (breaking pain), Sphotana (bursting pain), Vidarana (perforating pain), Utpatana (tearing pain), Kampana (tremoring pain), Vislesana (dislocating pain), Vikirana (radiating pain), Purana (distending pain), Stambhana (stiffness/ ankylosing pain), Swapana/ Swapa (anaesthesia), Akuncana (spasmodic pain), Ankusika (anchoring/ hanging pain), Atimatra Vedana (sudden excessive pain), Vividha Shoola (different pain).

Paittika Vedana:- Osa (burning pain), Chosa (scalding pain), Paridaha (burning sensation all around), Dhumayana (sensation of hot smoke), Gatrangaravakirnamiva pacyate (sensation of touch by burning coal), Usmabhivriddhi (increased temperature), Kshate ksharavasiktavaccha Vedana (caustic application overwound like pain).

Kaphaja Vedana:- Alpavedanama (mild pain), Suptatvama (numbness), Avedanam/Aruja (analgesia), Parsvasubheda (pain in flanks)

Tridosaja/ Sannipataja Vedana: - Vividha Vedana (different kinds of pain), Sarva Vedana (all kinds of pain).

\section{THE SITES OF PAIN ${ }^{18}$}

The sites of pain are the precordial region, flanks, back, sacral and suprapubic regions.

- The Vatika Sula is characterized by being spasmodic having periods of exacerbations and remissions repeatedly with the retention of urine, flatus and faeces. It can be identified as a pricking or tearing type of pain.

- The Paittika Sula is very severe and sudden in onset. The colicky pain is associated with thirst, fainting, burning sensation and pain in the umbilical region. Excessive perspiration, vertigo is also accompanied by the Paittika Sula.

- The Kaphaja Sula is low-intensity colicky pain in the abdomen. It is associated with nausea, cough, malaise, anorexia, excessive salivation, and heaviness of the abdomen. The colicky pain is aggravated after meals and in the early morning. In Sannipataja Sula all three Dosas get vitiated. The clinical presentation may be varied accordingly. All the symptoms may be in an aggravated state.

\section{MANAGEMENT OF PAIN-}

The management of pain comprises a multi-fold approach. It can be categorized into local management and systemic management. The pain caused by traumatic lesions can be managed by local fomentation, irrigation, application of local medicament and bandaging. In Ayurveda, the term Vedana is more or less used for the feeling. It may be the feeling of wellbeing or the feeling of illness (Sukhatamaka and Dukhatmaka). ${ }^{19}$ In Ayurveda, there is no particular uniform medicine for any kind of pain. Management of pain depends upon the causative factor or Doshika predominance responsible for the pain. In conventional (allopathic) pain treatment several analgesics, anti-inflammatory, antipyretic drugs, chemo trypsin and serratiopeptidase like chemicals and opioids are used, but there is no universal drug for all kinds of pain to date. Every individual response to pain in a different way. In the same way, every analgesic chemical acts pharmacologically in a different way. Only one analgesic preparation cannot solve the problem of pain. So, the management of pain is not so simple and satisfactory with the aforesaid drugs. Instant pain relief is the motive of Marma therapy. Stimulation of Marma can produce analgesia by secreting several prostaglandin inhibitors, endorphins, interferon and other opioid-like substances which are a hundred times more potent than opium. Instant pain relief by Marma therapy is possible within no time.

Following Marma points are responsible for the relief of pain in different organs.

1. Shoulder pain - Kshipra marma and Kurpara marma.

2. Pain in abdomen - Kurpara and Urvi marma. 
3. Chest Pain - Kurpara, Urvi and Ani.

4. Cervical (neck) pain - Kshipra, Kurpara, Ani marma

5. Leg and knee pain - Kshipra, Gulpha

6. Sciatic pain - Kshipra, Gulpha

Pain management aims at minimizing distress, feeling of unrest, and improving the quality of life. A cardinal point in the management of pain is that it should be holistic and patient-centred in its application. This can be fulfilled in the Ayurvedic approach only in terms of Marma Chikitsa. ${ }^{20}$

\section{DISCUSSION}

In Ayurveda, the term Vedana is more or less used for the feeling. It may be the feeling of well-being or the feeling of illness. The governance of all kinds of body sensations is the subject of the Vata. But during the vitiation of Vata, all these functions get disturbed and the excessive activity of vitiated Vata may cause pain sensation. From the above and according to the literature we can conclude that Marmas should be stimulated in every type of pain for its analgesic effect. Every Marma points have their measures, so Marmas points should be stimulated to their measures.

\section{CONCLUSION}

The present article shows the mode of action of Marma Chikitsa, as suggested in the literature, which has been discussed. The special capability of Marma Chikitsa in Treating any kind of pain disorders, Thus, it can be concluded that Marma science, which is an extremely ancient field of Facts, holds significant promise in being used to maintain the vitality of the body and treatment of diseases.

\section{REFERENCES}

1. Dr Sunil Kumar Joshi. Marma Science and Principles of Marma Therapy, New Delhi, Vani Publications, 2019 page-11

2. Shastri Dr. Ambika Dutta. Sushrut Samhita, Ayurved Tattva Sanddipika Varanasi, Chaukhamba Sanskrit sansthan Varanasi, 2012. Su. Sharir 6/1page-67

3. Bhishagratna Kaviraj Kunjlal. Sushrut Samhita, An English Translation Of Sushrut Samhita Culcutta,
Kashi Ghodse Lane, 1911. Su. Sharir 6/22, Vol 2, page176

4. Shastri Dr. Ambika Dutta. Sushrut Samhita, Ayurved Tattva Sanddipika Varanasi, Chaukhamba Sanskrit sansthan Varanasi, 2012. Su. Sharir 5/6page-55

5. Ghanekar Dr. Bhaskar Govind. Ayurveda Rahusya Deepika Hindi commentary on Sushruta Samhita Sharir Sthanam. New Delhi, Mehar Chand Lachmandas Publication 1998. Su. Sharir 6/2 page 183

6. Joshi Dr Sunil Kumar. Marma Science and Principles of Marma Therapy, New Delhi, Vani Publications, 2019 page-33

7. Joshi Dr Sunil Kumar. Marma Science and Principles of Marma Therapy, New Delhi, Vani Publications, 2019 page- 40

8. Tortora, Gerard J. Principal of Anatomy and Physiology, Hoboken, NJ: J. Wiley, 2006. $13^{\text {th }}$ edition. Page no.612

9. Tortora, Gerard J. Principal of Anatomy and Physiology, Hoboken, NJ: J. Wiley, 2006. $13^{\text {th }}$ edition. Page no. 613

10. Joshi Dr Sunil Kumar. Marma Science and Principles of Marma Therapy, New Delhi, Vani Publications, 2019 page-51

11. Shastri Dr. Ambika Dutta. Sushrut Samhita, Ayurved Tattva Sanddipika Varanasi, Chaukhamba Sanskrit sansthan Varanasi, 2012. Su. Sha.6/33page-74

12. Shastri Dr. Ambika Dutta. Sushrut Samhita, Ayurved Tattva Sanddipika Varanasi, Chaukhamba Sanskrit sansthan Varanasi, 2012. Su. Sutra 17/12page-94

13. Joshi Dr Sunil Kumar. Marma Science and Principles of Marma Therapy, New Delhi, Vani Publications, 2019 page-52

14. Sharangdhra, Sharangdhara Samhita, Choukhamba Surbharti Prakashan, Varanasi, reprint 2012-13. Sh.Pu.5/25page22.

15. Shastri Dr. Ambika Dutta. Sushrut Samhita, Ayurved Tattva Sanddipika Varanasi, Chaukhamba Sanskrit sansthan Varanasi, 2012. Su. Sha.6/17page-70

16. Sukla Acharya Vidyadhara.Charak Samhita. Charak Samhita Of Agnivesha, Choukhamba Sanskrit Prakashan Delhi, 2013. Ch. Su.18/1-4.page 275-276

17. Shastri Dr. Ambika Dutta. Sushrut Samhita, Ayurved Tattva Sanddipika Varanasi, Chaukhamba Sanskrit sansthan Varanasi, 2012. Su. Su.17/5page-92

18. Joshi Dr Sunil Kumar. Marma Science and Principles of Marma Therapy, New Delhi, Vani Publications, 2019 page-53 
19. Joshi Dr Sunil Kumar. Marma Science and Principles of Marma Therapy, New Delhi, Vani Publications, 2019 page-54

20. Joshi Dr Sunil Kumar. Marma Science and Principles of Marma Therapy, New Delhi, Vani Publications, 2019 page- 55

\section{Source of Support: Nil \\ Conflict of Interest: None Declared}

How to cite this URL: Dhakad Jyoti at al: A Review - Pain Management Through Marma Chikitsa. International Ayurvedic Medical Journal \{online\} 2021 \{cited July 2021\} Available from:

http://www.iamj.in/posts/images/upload/1529_1533.pdf 